\title{
Evaluation of Efficiency of Propagation Techniques Tree Oil Species Karanja (Pongamia pinnata (L.) Pierre)
}

\author{
T. Shobha Rani ${ }^{*}$, U. Nagabhushanam ${ }^{2}$, T. Sukruth Kumar ${ }^{3}$ and P. Raghu Ram Reddy ${ }^{4}$ \\ ${ }^{1}$ Department of Plant Breeding, ${ }^{2}$ Department of Agronomy, \\ ${ }^{3}$ Department of Soil Science, Professor Jaya Shankar Telangana State Agricultural \\ University, Agricultural Research Station, Nathnaipally, Narsapur, Medak- 502 313, India \\ ${ }^{4}$ Associate Director of Research, Professor Jaya Shankar Telangana State Agricultural \\ University, Agricultural Research Station, Nathnaipally, Narsapur, Medak- 502 313, India
}

*Corresponding author

\section{A B S T R A C T}

\section{Key words \\ Tree oil species, Flowering, Fruiting, PSB, Pongamia pinnata, Seed production \\ Article Info \\ Accepted: \\ 15 July 2018 \\ Available Online: \\ 10 August 2018}

The study was aimed to determine the potency of seeds and seedlings production of Karanja in relation to the procurement of planting stocks for plantation programmes. The methods were observing of flowering and fruiting development, measuring of seeds production and examining of seedlings quality and quantity. It was concluded that a proper fruit collecting time can be determined from the period of flowering and fruiting development and reproductive potency can be utilized for estimating the potency of seeds production. Stem diameter of the tree can be used to predict the produced seeds and seedlings. Seedlings quality can be improved by giving a treatment of $2.5 \mathrm{~g}$ PSB $+1.0 \mathrm{~g}$ NPK fertilizer.

\section{Introduction}

National's policy on the continuation of energy is based on three core dimensions: energy security, social equity and environmental impact mitigation. These three goals require firm action to turn the national energy system onto sustainable and environmentally sensitive energy system (Situmeang, 2013). Hence, to face the challenge on the demand of energy in the future, there is a need to develop bio-energy instead of fossil energy. It is predicted that India will run out of fossil energy sources in the near future due to the limited supply of natural gas, the increasing of oil price, inefficient use of energy. Therefore, the sustainable energy sources should be concerned and one of the strategy to meet increasing demand is to accelerate the development of clean energy such as renewable and alternative energy (Situmeang, 
2013). India has been targeting a new and renewable share of $23 \%$ in the national energy mix up in year 2025. In supporting the demand of new and renewable energy, the use of biomass-based biofuels is needed and several forest tree species can be utilized as a source of raw materials.

Karanja (Pongamia pinnata (L.) Pierre) is a bio-energy tree legume with the potential for high oil seed production and the added benefit of the ability to grow on marginal land (Scott et al., 2008). Currently, the existing stands of Karanja in India are naturally grown. One of constraints that limit its large-scale production and availability to meet the need of bio-energy production, is lack of knowledge on its cultivation. The successful of plantation program is strongly dependent on the existence of seeds and seedlings procurement. The procurement of seeds and seedlings continuously need basic information on the period of flowering and fruiting, the potency of produced seeds and seedlings, as well as seedling techniques of the species.

The nature phenomenon occurs on a plant life cycle such as leave flushing, flowering and fruiting vary according to environmental condition, especially when the species are enable to live in a wide range of edaphic and climate types (Bawa et al., 1990). Any species of trees possess different characteristics of flowering and fruiting pattern, but mostly begins with the appearance of flower buds and ends with fruit ripening. Observation on a floral phenology of Swietenia macrophylla topped with the evaluation of fruit ripening level (Lovelless et al., 2013).

Seed production of a stand or a tree in each periods of fruiting will fluctuate that causing miss estimation of the produced seeds. This is due to inappropriate of seed collecting time and inefficient of the implementation. Therefore, in measuring seed production it should be correlated with geographical conditions, growth performances and tree ages. The size of tree and form of the canopy are factors that influence the frequency, intensity and periods of fruiting, as well as the factors of ages, healthy, light and climates. In relation to achieve a high quality and quantity of seedling production, it is necessary to pay attention to the seedling growth in a nursery which are concerning on growing media. This review assesses and integrates the floral phenology, seed production and seedling handling of Karanja (Pongamia pinnata) in relation to determine their potency for plantation program.

\section{Materials and Methods}

The study was carried out at Agricultural Research Station, Nathnaipally is situated in Narsapur Mandal, Medak District, Telangana, India. Its geographical coordinates are $17^{\circ} 44^{\prime}$ 9" North, 78 16' 54" East on globe. The environment in area is tropical. Farming system is rainfed and soil type is Red sandy loam (shallow-medium). It is characterized by the annual rainfall of $732.5 \mathrm{~mm}$ and temperatures ranging from $15^{\circ} \mathrm{C}$ to $45^{\circ} \mathrm{C}$.

\section{Reproductive development and fruit set}

The inflorescences were observed individually for flowering and fruiting development including flower buds, developing flower and fruit development (from fruit initiation until maturation). Five branches that bearing inflorescences at the west and east of the tree canopy were randomly tagged with colored ribbon and every developed inflorescence was labelled. Any changes of flowering to fruiting structures were recorded by taking notes of time (date and period), shape and color. The number of flowers and fruits were calculated for measuring the fruit set and evaluating its potency. Data were analyzed by using paired t-test. Comparative test between two-paired 
values of western and eastern of inflorescencebearing branches was employed for each sample tree.

\section{Seed and seedling production}

Sample trees of 25 were selected to assess seed production of Karanja. Tree dimension of total height, stem diameter and canopy width were measured. Data were analyzed by using correlation test to evaluate the relationship between tree dimensions and the number of produced seeds. Seedling production was measured by calculating the numbers of seeds per tree multiply by the number of normally germinated seeds and survived seedlings.

\section{Seedling techniques}

There are two treatments applied to the one month old seedlings of Karanja, 1. An organic fertilizers of NPK 15: 15: 15 (0, 0.5 and $1.0 \mathrm{~g})$ for each seedling, 2. inoculation of PSB (Phospho Bacteria) of $(0,2.5$ and $5.0 \mathrm{~g})$ for each seedling.

The experiment was arranged in a factorial randomized-completed design with 9 replications. Five months after treatments, growth was assessed by measuring seedling growth, inoculants effectiveness and infectivity and P-uptake.

Root colonization was measured to find out their infectivity in the root and formulated as follows:

Infected root $=\frac{\sum \text { infected root sample }}{\sum \text { observed root sample }}$
-

Samples were wet oxidized with $\mathrm{HNO}_{3}$ and $\mathrm{HCLO}_{4}$.

The extract was used to analyse $\mathrm{P}$ element which was using spectrophotometry method.

\section{Results and Discussion}

\section{Fruit/flower ratio}

The number of flowers and fruits in the west are less than those in the east (Table 1). Randomly sampled, the ratio of fruits/flowers (fruit set) of Karanja in the west is around 38 $\%$ to $88 \%$ and in the east is $43 \%$ to $89 \%$. Thus, the potency of flowers to fruits in average at the west and east are $63 \%$ and 66 $\%$, respectively. Each species will genetically produce different values of fruit set that refer to the characteristics of flowering and fruiting itself. Plants with more abundance flowers may have less pollen limitation. A greater variance of fruit set over years may occur when pollination was carried out by the majority of floral visitors. In general, fruit set is influenced by many factors of environments, breeding system evolution, pollination system and biogeography (Berjano et al., 2006).

Statistics analysis showed that there is no significantly difference between flowering in the West and East in relation to the reproductive variables such as number of flower, number of fruit and fruit set (Table 2).

\section{Flowering and fruiting development}

Floral development from generative buds to the appearance of flower buds that grew at the West and East of the branches took about 19 to 23 days and 18 to 23 days respectively. The changes from flower buds to the developed ovaries and small young fruits in the west and east were approximately of 44 to 66 days and 35 to 73 days (Table 3 ).

The periods of each stage of flowering and fruiting development located in the west and east of the branches did not show a significant difference following paired t-test $(\mathrm{P}>0.05)$ (Table 4). 
The ratio of flowers to fruits of karanja and the periods of flowering and fruiting development stages do not distinguish the behaviour of flowering and fruiting in two different sun directions of the West and East. The sun's rays are emitted in all directions and only a small percentage received by the earth. Geographically, the west and east receive relatively the same light intensity. The differences occur when the cloud or rain impedes solar radiation.

In addition, planting distances of karanja in ARS, Nathnaipally are relatively closed each other $(5.0 \times 5.0 \mathrm{~m})$ and canopy closure are dense, thus the incoming light is more or less the same. Therefore, the growth and development of floral and fruit of karanja in the West and East in the same tree receive a similar intensity of solar radiation.

Regardless the sun direction of the West and East, mostly generative buds of karanja occur in December and developed to be flower bloom in January-February that proceeds for about 5 to 7 days. When, the flowers pollinated, the ovaries become bigger and developed to be young fruits. This phase was seen in February and become mature fruits in April. Overall, the cycle of flowering and fruiting of karanja lasts for 7 to 8 month.

\section{Seed and seedling production}

The age of karanja natural stands in ARS, Nathnaipally is approximately more than $8 \mathrm{yr}$ old, with the stem diameter and height total of $21.53 \mathrm{~cm} \pm 6.7 \mathrm{~cm}$ and $9.36 \mathrm{~m} \pm 1.4 \mathrm{~m}$ in average, respectively. The number of seed production collected in 2018 were $1.41 \mathrm{~kg}$ tree $^{-1} \pm 1,56 \mathrm{~kg}$ tree ${ }^{-1}$ or around $2.0 \mathrm{~kg}$ tree $^{-1}$ to $3.3 \mathrm{~kg} \mathrm{~kg}$ tree ${ }^{-1}$. Seed production was negatively correlated to the stem diameter $(\mathrm{P}<$ 0.05). Thus, the increase of stem diameter would be followed by the reduction of the produced seeds (Figure 1). This might be due to the relatively closed of planting distance among the trees, i.e. $2.49 \mathrm{~m} \pm 0.80 \mathrm{~m}$.

The dense of planting distance causes the tree crowns do not develop well and make a limitation to the fruit bearing branches, eventually. The supply of energy to set up fruit production is depend on the green leaf surface area. Indirectly stem diameter affect to the seed production, but tree crown does directly (Chaoyan et al., 2012). Therefore, the approach of silvicultural techniques application for karanja should pay attention to the most influence factors on tree productivity, among others are planting distance and fertilization arrangement. It was suggested that planting distance of $5 \mathrm{~m}$ was enable to produce seeds of karanja of around $10 \mathrm{~kg}$ tree ${ }^{1}$ to $250 \mathrm{~kg}^{-1} \mathrm{tre}^{-1}$ (Kesari and Rangan., 2010). Thus, it is possible to increase the production of karanja seeds in ARS, Nathnaipally by thinning, so that the distance among trees would be wider.

The allometric equation for the estimation of karanja seed production in ARS, Nathnaipalyy is $\log \mathrm{Y}=1.334-1.06 \log \mathrm{X}_{1}$, where $\mathrm{Y}$ is seed production $\left(\mathrm{kg}\right.$ tree $\left.^{-1}\right)$ and $X_{1}$ is stem diameter $(\mathrm{cm})$. Based on determination coefficient ( ${ }^{2}{ }^{2}$ adj), it was found that $31.12 \%$ of seed production variation was influenced by stem diameter. In this case, there were others independent variables affected that cannot be explained by such regression equation. The factors are including soil and climate conditions.

Seedling production of karanja was measured based on the estimation of seed production. It was found out that seed production of karanja per tree in ARS, Nathanaipally was $0.2 \mathrm{~kg}$ to $3.3 \mathrm{~kg}$ or equal to 155.8 seeds to 2570.7 seeds (the number of seed per $\mathrm{kg}$ is 799 seeds). Germination testing of the seeds resulted a germination capacity of $60 \%$ and survived seedlings of $95 \%$. 
Table.1 Number of flowers and fruits per inflorescence of Karanja at ARS, Nathnaipally

\begin{tabular}{|l|l|l|l|l|l|l|}
\hline S. No & \multicolumn{3}{|c|}{ West } & \multicolumn{3}{|c|}{ East } \\
& $\begin{array}{l}\text { (yield } \pm \text { se) } \\
\text { Flowers } \\
\text { inflorescence }\end{array}$ & $\begin{array}{l}\text { (yield } \pm \text { se) } \\
\text { Fruit } \\
\text { Inflorescence }\end{array}$ & $\begin{array}{l}\text { (Fruit set } \\
\text { yield } \pm \text { se) }\end{array}$ & $\begin{array}{l}\text { (yield } \pm \text { se) } \\
\text { Flowers } \\
\text { Inflorescence }\end{array}$ & $\begin{array}{l}\text { (yield } \pm \text { se) } \\
\text { fruit } \\
\text { inflorescence }\end{array}$ & $\begin{array}{l}\text { (Fruitset) } \\
\text { (yield } \pm \text { se) }\end{array}$ \\
\hline 1 & $(52.2 \pm 7.3)$ & $(24.6 \pm 8.2)$ & $(0.48 \pm 0.1)$ & $(56.8 \pm 9.6)$ & $(45.2 \pm 7.3)$ & $(0.79 \pm 0.0)$ \\
\hline 2 & $(53.8 \pm 13.8)$ & $(40.4 \pm 6.8)$ & $(0.77 \pm 0.1)$ & $(57.2 \pm 7.5)$ & $(37.0 \pm 8.2)$ & $(0.65 \pm 0.1)$ \\
\hline 3 & $(55.8 \pm 8.4)$ & $(24.5 \pm 8.8)$ & $(0.47 \pm 0.2)$ & $(53.0 \pm 7.1)$ & $(36.0 \pm 1.4)$ & $(0.68 \pm 0.1)$ \\
\hline 4 & $(56.6 \pm 7.5)$ & $(39.8 \pm 6.6)$ & $(0.71 \pm 0.1)$ & $(53.4 \pm 11.1)$ & $(31.2 \pm 6.7)$ & $(0.58 \pm 0.1)$ \\
\hline Mean & $(54.6 \pm 13.8)$ & $(36.2 \pm 4.2)$ & $(0.70 \pm 0.2)$ & $(51.7 \pm 4.0)$ & $(30.7 \pm 5.5)$ & $(0.59 \pm 0.1)$ \\
\hline
\end{tabular}

$* \mathrm{se}=$ standard error.

Table.2 Paired t-test of the influence of two-sun directions on reproductive variables of karanja

\begin{tabular}{|l|c|l|l|l|}
\hline Variables & West & & East \\
\hline Number of flowers & 54.6 & $\mathrm{a}$ & 54.4 & $\mathrm{a}$ \\
\hline Number of fruits & 33.1 & $\mathrm{a}$ & 36.0 & $\mathrm{a}$ \\
\hline Fruit set & 0.63 & $\mathrm{a}$ & 0.66 & $\mathrm{a}$ \\
\hline
\end{tabular}

* Mean values followed by the same alphabet are not significantly different at $\alpha: 0.05$

Table.3 The periods of flowering-fruiting development (days) of karanja at the West and East of branches

\begin{tabular}{|c|c|c|c|c|c|}
\hline \multirow[t]{2}{*}{ Developmental Stages } & \multicolumn{5}{|c|}{ No. of Trees } \\
\hline & 1 & 2 & 3 & 4 & 5 \\
\hline \multicolumn{6}{|l|}{ West } \\
\hline $\begin{array}{l}\text { Flower buds periods } \pm \\
\text { se }\end{array}$ & $(20.0 \pm 1.5)$ & $(22.0 \pm 1.52)$ & $(22.0 \pm 6.3)$ & $(23.0 \pm 5.9)$ & $(19.0 \pm 6.2)$ \\
\hline $\begin{array}{l}\text { Developed Ovary } \\
\text { periods } \pm \text { se }\end{array}$ & $(6.6 \pm 1.1)$ & $(7.6 \pm 2.07)$ & $(7.2 \pm 2.4)$ & $(10.0 \pm 3.1)$ & $(7.0 \pm 2.16)$ \\
\hline $\begin{array}{l}\text { Small Young fruit } \\
\text { periods } \pm \text { se }\end{array}$ & $(36.6 \pm 10.7)$ & $(56.2 \pm 14.4)$ & $(42.2 \pm 17.4)$ & $(41.4 \pm 9.5)$ & $(39.2 \pm 9.8)$ \\
\hline Total days \pm se & $(63.2 \pm 14.4)$ & $(85.8 \pm 20.6)$ & $(71.4 \pm 15.2)$ & $(74.4 \pm 14.9)$ & $(65.2 \pm 13.7)$ \\
\hline \multicolumn{6}{|l|}{ East } \\
\hline $\begin{array}{l}\text { Flower buds periods } \pm \\
\text { se }\end{array}$ & $(21.6 \pm 2.7)$ & $(19.2 \pm 2.8)$ & $(20 \pm 5.4)$ & $(22.6 \pm 5.8)$ & $(17.6 \pm 5.3)$ \\
\hline $\begin{array}{l}\text { Developed Ovary } \\
\text { periods } \pm \text { se }\end{array}$ & $(5.0 \pm 1.2)$ & $(6.8 \pm 0.8)$ & $(6.6 \pm 2.1)$ & $(6.4 \pm 2.0$ & $(6.33 \pm 1.7)$ \\
\hline $\begin{array}{l}\text { Small Young fruit } \\
\text { periods } \pm \text { se }\end{array}$ & $(32.8 \pm 2.1)$ & $(44.0 \pm 1.4)$ & $(50.1 \pm 6.7)$ & $(35.4 \pm 10.7)$ & $(17.1 \pm 1.2)$ \\
\hline Total days \pm se & $(59.4 \pm 11.8)$ & $(70.0 \pm 15.7)$ & $(76.6 \pm 18.5)$ & $(64.4 \pm 12.8)$ & $(65.6 \pm 15.2)$ \\
\hline
\end{tabular}


Table.4 Paired t-test of the influence of two-sun direction on the flowering and fruiting periods of karanja

\begin{tabular}{|l|c|c|c|c|}
\hline Developmental Stages & \multicolumn{3}{|c|}{ West } & \multicolumn{2}{|c|}{ East } \\
\hline Flower buds (days) & 21.20 & A & 20.20 & a \\
\hline Developed ovary (days) & 7.68 & A & 6.23 & a \\
\hline Small young fruit (days) & 43.13 & A & 40.78 & a \\
\hline
\end{tabular}

Mean values followed by the same alphabet are not significantly different at $\alpha: 0.05$

Table.5 Mean values of the effect of PSB and fertilizer on the seedlings growth of five months old karanja

\begin{tabular}{|c|c|c|c|c|c|}
\hline Treatments & $\begin{array}{l}\text { Seedling } \\
\text { Height } \\
(\mathrm{cm})\end{array}$ & $\begin{array}{l}\text { Seedling } \\
\text { Diameter } \\
(\mathrm{cm})\end{array}$ & $\begin{array}{l}\text { Survival } \\
\text { Percentage } \\
(\%)\end{array}$ & $\begin{array}{l}\text { Dry } \\
\text { Organic } \\
\text { matter }(\mathbf{g})\end{array}$ & $\begin{array}{l}\text { Root } \\
\text { Colonization } \\
(\%)\end{array}$ \\
\hline Untreated Seedlings & 13.9 & $4.15 b$ & 90.64 & 3.18 & 15.70 \\
\hline $0 \mathrm{~g}$ PSB + $0.5 \mathrm{~g}$ fertilizer & 17.4 & $4.77 \mathrm{~b}$ & 94.64 & 3.12 & 78.83 \\
\hline $0 \mathrm{~g}$ PSB +1.0 g fertilizer & 16.7 & $4.34 \mathrm{~b}$ & 97.32 & 5.00 & 67.00 \\
\hline $0 \mathrm{~g}$ fertilizer $+2.5 \mathrm{~g}$ PSB & 11.1 & $3.23 \mathrm{~b}$ & 79.96 & 3.65 & 54.43 \\
\hline $0 \mathrm{~g}$ fertilizer $+5.0 \mathrm{~g}$ PSB & 12.0 & $3.78 \mathrm{~b}$ & 85.30 & 2.77 & 34.96 \\
\hline $2.5 \mathrm{~g}$ PSB + $0.5 \mathrm{~g}$ fertilizer & 16.8 & $4.06 \mathrm{~b}$ & 89.32 & 3.29 & 52.20 \\
\hline $2.5 \mathrm{~g}$ PSB +1.0 g fertilizer & 11.8 & $10.47 \mathrm{a}$ & 87.96 & 3.48 & 70.53 \\
\hline $5.0 \mathrm{~g}$ PSB $+.0 .5 \mathrm{~g}$ fertilizer & 17.0 & $3.30 \mathrm{~b}$ & 77.28 & 2.70 & 84.96 \\
\hline $5.0 \mathrm{~g}$ PSB +1.0 g fertilizer & 15.7 & $4.00 \mathrm{~b}$ & 86.64 & 3.62 & 75.50 \\
\hline
\end{tabular}

Mean values followed by the same alphabet are not significantly different at $\alpha: 0.05$

Table.6 The infectivity and effectiveness of inoculants on the increment growth of karanja seedlings

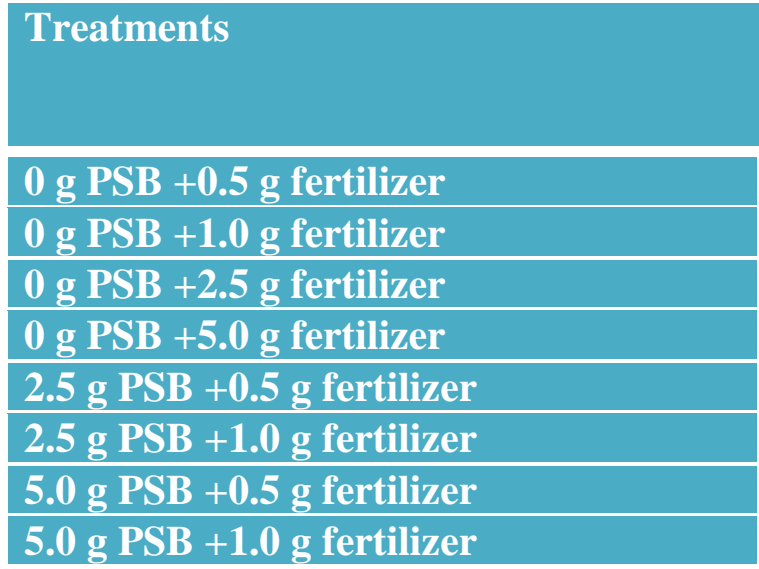

\begin{tabular}{|c|c|c|}
$\begin{array}{c}\text { Height } \\
\text { Increment } \\
(\%)\end{array}$ & $\begin{array}{c}\text { Diameter } \\
\text { increment } \\
(\%)\end{array}$ & $\begin{array}{c}\text { Dry organic } \\
\text { matters } \\
\text { increment }(\%)\end{array}$ \\
\hline 25.17 & 14.93 & -1.88 \\
\hline 20.14 & 4.57 & 57.23 \\
\hline-20.14 & -22.16 & 14.77 \\
\hline 20.86 & -2.16 & 3.45 \\
\hline-15.10 & 152.28 & 9.43 \\
\hline-13.66 & -8.91 & -12.89 \\
\hline 22.30 & -20.48 & -15.09 \\
\hline 12.94 & -3.61 & 35.79 \\
\hline
\end{tabular}


Table.7 Inoculant effectiveness of the increment of P- uptake

\begin{tabular}{|l|c|c|}
\hline Treatment & $\begin{array}{c}\text { Root colonization } \\
\text { increment }(\%)\end{array}$ & $\begin{array}{c}\text { P-uptake } \\
\text { increment (\%) }\end{array}$ \\
\hline Untreated & 57.86 & 0.28 \\
\hline Fertiliser $0.5 \mathrm{~g}$ & 37.3 & 30.5 \\
\hline Fertiliser 1.0g & 15.69 & -94.91 \\
\hline PSB 2.5 g & -5.98 & 118.64 \\
\hline PSB 2.5 g + Fertilizer 0.5 g & -37.57 & 66.1 \\
\hline PSB 2.5 g + Fertilizer 1.0 $\mathrm{g}$ & -10.29 & 220.33 \\
\hline PSB 5.0 g & 25.05 & -30.5 \\
\hline PSB 5.0 g + Fertilizer 0.5 g & 46.45 & 13.55 \\
\hline PSB 5.0 g + Fertilizer 1.0 g & 33.41 & -1642.37 \\
\hline
\end{tabular}

Fig.1 Seed production versus diameter of karanja at ARS, Nathnaipally

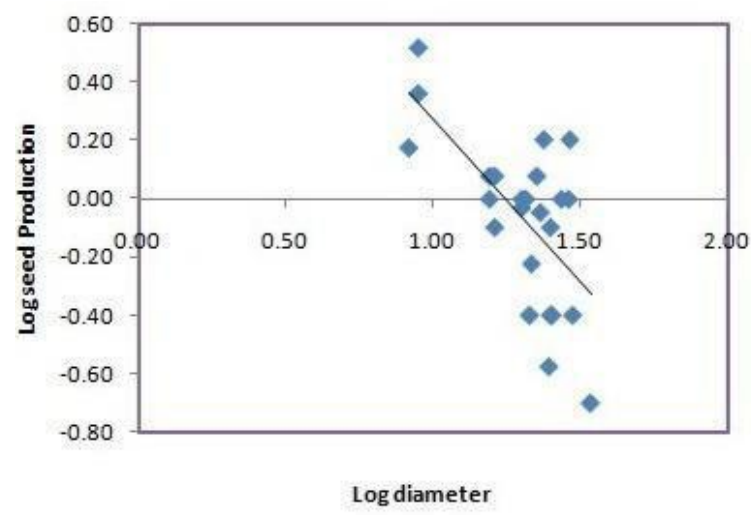

Considering of these values, it was counted that the number of seedlings produced from one tree was around 89 seedlings to 1465 seedlings. Thus, to fulfil the demand of karanja seedlings for plantation of e.g. one hectare with a planting distance of $5 \times 5 \mathrm{~m}$, the number of seeds needed was about $2.5 \mathrm{~kg}$, which come from the calculation of:

NS's

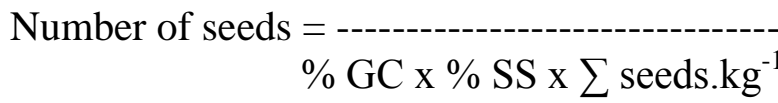

Where:

NS's: Number of seedlings

GC: Germination capacity
SS: Survived seedlings

Two and half $\mathrm{kg}$ of seeds can be gathered from only (1 to 2 ) trees. However, concerning of a wide genetic variation of the seeds that should be used for gaining a better quality stand, a bulk of seeds is preferably harvested from a lot of improved mother trees (Finkeldey, 2005).

\section{Seedling quality}

\section{Seedling growth}

Five months after treatments, the survived seedlings of karanja were high and gave a significant difference on the growth of the 
seedlings height and diameter. The interaction between treatment of $2.5 \mathrm{~g}$ PSB and fertilizer of $1.0 \mathrm{~g} \mathrm{NPK}$ gave diameter value of 10.47 $\mathrm{mm}$ or around $152.3 \%$ increasing compared to the value of non-treatment. The combination of $5 \mathrm{~g}$ PSB and $0.5 \mathrm{~g}$ NPK fertilizer gave a high value of root colonization $(84.96 \%)$ but showed no difference with other treatments (Table 5).

\section{Inoculants infectivity and effectiveness to the seedling growth}

The obtained values of inoculants infectivity and effectiveness of the treatments were compared with the values of seedlings growth without treatment (control). Seedling height, diameter and dry organic matters of the untreated seedlings were $4.00 \mathrm{~cm}, 86.64 \mathrm{~mm}$ and $3.62 \%$, respectively. Some of the treatments were unable to increase the seedlings growth of karanja determined from the negative values (Table 6).

Dry organic matters of the seedlings are an indicator of the success of seedling growth. The mass of dry matters imply the occurrence of net photosynthesis that can be deposited after drying of moisture content. The increase of biomass shows the productivity of rapid cell tissues establishment.

The effectiveness of PSB utilization on the root colonization and P-uptake were formulated as follows: and measured by calculating their relative increment (Table 7).

(Treated - untreated) X $100 \%$

Untreated

PSB colonization will increase the uptake of phosphate due to the availability of phosphatase enzyme played in mineralization of organic phosphate. In this study the improvement of relative phosphate uptake by the seedlings treated with $2.5 \mathrm{~g}$ PSB at concentration of $1.0 \mathrm{~g}$ fertilizer shows that the PSB could create colonization. Phosphate element accelerates cell division especially on the development of plant meristem tissues which is important in the growth of seedlings.

There were no different characteristics of flowering and fruiting of karanja regarding to the sun direction of the west and east located in ARS, Nathnaipally. The potency of flowers to fruits in average in the west and east were $63 \%$ and $66 \%$, respectively. In general, the period of flowering and fruiting development took around 7 mo to 8 mo that began in March -April and lasted as matured fruits in October-November. There was negative correlation between seed production and stem diameter. The allometric equation for the estimation of karanja seed production in ARS, Nathnaipally was $\log \mathrm{Y}=1.334-1.06 \log \mathrm{X}$. Seedling production of karanja can be calculated based on the estimation of seed production. The number of seedlings per tree was around (89 to 1 465) seedlings. Combination of $2.5 \mathrm{~g}$ PSB and $1.0 \mathrm{~g} \mathrm{NPK}$ fertilizer treatments given to the seedlings of karanja would increase phosphate uptake of $220.33 \%$ compared to the untreated seedlings.

\section{References}

Bawa KS, Ashton PS and Noor SM., 1990. Reproductive ecology of tropical forest plants: management issue. In: Reproductive ecology of tropical forest plants. Bawa KS, Hadley M, editors. France: UNESCO Paris and the Parthenon Publishing Group. p. 3- 11.

Berjano R, de Vega C, Arista M, Ortiz PL and Talavera S., 2006. A multi-year study of recemes affecting fruit production in Aristolochia paucinervis (Aristolochiaceae). American Journal of Botany 93:599-606. 
Chaoyan LV, Zhang X, Liul G and Deng C., 2012. Seed yield model of Haloxylon ammodendron (c.a. meyer) bunge in Junggar Basin, China. Pak. J. Bot. 44(4):1233-1239.

Finkeldey R., 2005. An introduction to tropical forest genetics. Djamhuri E, Siregar IZ, Siregar UJ, Kertadikara AW, tranl's. Gottingen: Institute of Forest Genetics and Forest Tree Breeding. Faculty of Forestry. Bogor Agricultural University.

Kesari V and Rangan L., 2010 Development of Pongamia pinnata as an alternative biofuel crop - current status and scope of plantations in India. J. Crop Sci. Biotech. 13(3):127-137.

Lovelless, Marylin D, Grogan and James, 2013. Flowering phenology, flowering neighborhood, and fruiting in Swietenia macrophylla, big-leaf mahagony, in Southern Para, Brazil; http://www. botanyconference.org/engine/search/ind ex.php? func $=$ detai $\&$ aid $=442$.

Scott PT, Pregelj L, Chen N, Hadler JS, Djordjevic MA and Gresshoff PM., 2008. Pongamia pinnata: untapped resource for the biofuels: industry of the furture. Bioenergy Research 1: 2-11.

Situmeang H., 2013. Energy security. In: Renewable Energy and Energy Conversion Conference and Exhibition: Road to Energy Security and People Welfare. Indonesia EBTKE-CONEX 2013. Jakarta.

\section{How to cite this article:}

Shobha Rani, T., U. Nagabhushanam, T. Sukruth Kumar and Raghu Ram Reddy, P. 2018. Evaluation of Efficiency of Propagation Techniques Tree Oil Species Karanja (Pongamia pinnata (L.) Pierre). Int.J.Curr.Microbiol.App.Sci. 7(08): 2806-2814. doi: https://doi.org/10.20546/ijcmas.2018.708.295 